\title{
Frond regrowth from basal disc in Iridaea laminarioides (Rhodophyta, Gigartinales) at Mehuín, southern Chile
}

\author{
Iván M. Gómez, Renato C. Westermeier \\ Instituto de Botánica, Facultad de Ciencias, Universidad Austral de Chile, Casilla 567, Valdivia, Chile
}

\begin{abstract}
Red algae of the family Gigartinaceae, including the genus Iridaea, have recently become of commercial importance as a primary source of carrageenans in the phycocolloid industry. This has led to excessive harvesting without any management plan. In southern Chile, $I$. laminarioides Bory has been of considerable interest not just because of its commercial value but also because of the interest in it for biological research. This study describes the formation of the erect frond from the crustose basal disc. This process allows survival of the population and maintains its competitive dominance in the rocky intertidal zone. Experimental pruning evaluated the optimum extent and frequency of pruning. Frond formation is a continuous process exhibiting a seasonal pattern; however, no significant differences in frond regrowth were found in pruning carried out at different seasons. Pruning frequency appeared to be a limiting factor affecting the regenerative ability of the basal disc. There was no evidence of any differences between the isomorphic phases in response to pruning. In all cases reproductive stages were reached after 6 mo.
\end{abstract}

\section{INTRODUCTION}

The capacity for regeneration of fronds from perennial basal disc is found widely among species of the Gigartinales (McLachlan et al. 1988, 1989); nevertheless, no detailed information exists describing the actual process or the determinant mechanisms. The presence of heteratrichy in species with an isomorphic life history represents an additional complicating factor in analysis of population strategy (Searles 1980, Perrone \& Felicini 1988). Hannach \& Santelices (1985) suggested that the variation between isomorphic phases in Iridaea species is determined by differing independent selective forces. Hansen (1977) related the presence of perennial discs in $I$. cordata with an increased abundance of tetrasporic plants, which may be correlated with greater environmental perturbations. Nevertheless, the previous studies on the gametophytic:sporophytic ratio in the Gigartinales are contradictory, making definition of a general pattern difficult.

Population studies conducted on Chilean Iridaea spp. have demonstrated that the presence of the basal disc permits spatial and temporal maintenance (Westermeier \& Rivera 1986, Gómez 1987, Westermeier et al.
1987 a). Nevertheless, patterns of biomass and isomorphic phase expression appear to be regulated by geographic factors. Guiller (1959) and Santelices (1981) describe a population structure in central Chile which is markedly seasonal, being characterized by low standing crop and dominated by the cystocarpic phase. In southern Chile I. laminarioides occupies a large part of the mid-intertidal level (Oliva 1967, Westermeier 1982, Jara \& Moreno 1983, Westermeier \& Rivera 1986), and presents a similar composition of the isomorphic phases (Westermeier et al. 1987a).

Currently, Iridaea laminarioides populations in southern Chile are being exploited for the extraction of carrageenans. Fortunately, market demands have not generated extreme exploitation (Ponce 1987); nevertheless, appropriate means of management should be adopted before this resource suffers greater deterioration. Taking into account these biological and productive factors, the ability of I. laminarioides populations to support the harvesting pressure will be determined, first, by the capacity for vegetative regrowth from the basal disc, and second, by the program of harvesting techniques. The present study evaluates the regenerative potential of the basal disc, analysing both phases of reproduction (cystocarpic and tetrasporic). 
Furthermore, experimental pruning helped to determine this response in relation to the frequency and time of the cut, with the goal of maximizing production through rational management.

\section{MATERIALS AND METHODS}

The present study was conducted from April 1985 to March 1986 in the rocky intertidal of Punta Kilian, Mehuin Bay, in the Province of Valdivia, Chile (Fig. 1). Biogeographically this region belongs to the cold

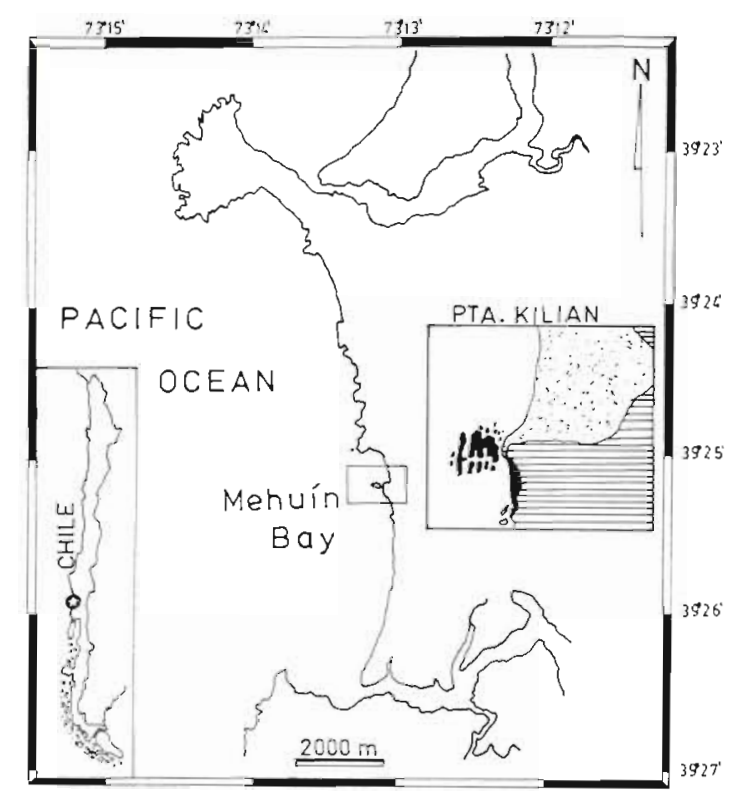

Fig. 1 Study area, showing the location of Punta Kilian
Magellanean Province (McLean 1978). Punta Kilian is a rocky prolongation of metamorphic origin, flanked by sand beaches subject to strong seasonal variations in profile (Pino 1982).

In the intertidal zone of Punta Kilian Iridaea laminarioides may be found coexisting as 2 alternative morphological stages: a naked perennial disc and a frondose phase in distinct stages of development. Fig. 2 shows the appearance of the $I$. laminarioides population in a rocky area semi-exposed to wave action. Four experimental areas (quadrats) of $1 \mathrm{~m}^{2}$ were considered. The first 2 were used as control areas. Area I consisted of 10 naked basal discs, which were used to observe the natural regeneration of fronds. In Area II, 10 frondose plants were marked and left unmanipulated. In the adjacent areas, experimental prunings were performed, consisting of cuts at the stipe level (III) and total removal of the fronds, including the stipe (IV). To determine the effect of frequency of pruning, in Area III, 2 groups of 10 plants were treated. The first was initially pruned, and was then left unmanipulated, while the second group was pruned every $15 \mathrm{~d}$.

In order to evaluate if there was a seasonal pattern in the response to pruning, different groups of 10 plants were pruned at the stipe level at distinct times of year. The density of fronds per $5 \mathrm{~cm}^{2}$ of basal disc and the frond length were quantified in each of the quadrats. The diameter of the basal disc, the density, the size of the fronds and corresponding isomorphic phase were registered at the begining of each experiment. To compare the effect of the treatments and of monthly variation, repeated testing of the same individuals using 2way Anova was performed, as described by Sokal \& Rohlf (1969). Months were considered as a random

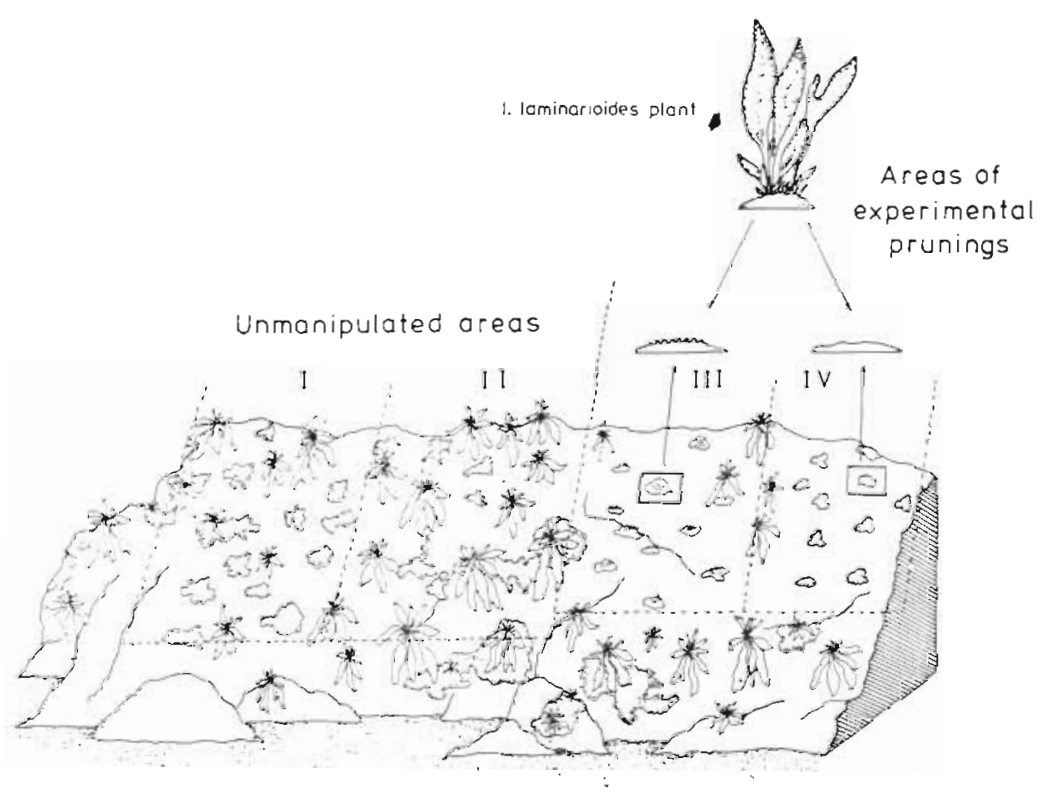

Fig. 2. Iridaea laminarioides. Schematic drawing of population inhabiting a semiexposed zone at southern Chile and the 4 experimental quadrats used in the study. For a more detailed explanation, see text 
factor serving as replication and treatments (pruning at stipe level, pruning flat to the disc and frondose control) as fixed. It is assumed that there was no interaction between months and treatments.

\section{RESULTS}

\section{Natural dynamics of frond regeneration}

The formation of fronds on the surface of the basal disc is not a uniform process, but rather one of patchy formation (Fig. 3). In the naked basal crust, regenerative activity was already observed during the first month, indicating that the absence of fronds on these discs is not a permanent situation under natural conditions. During the winter and early spring the density of newly formed fronds fluctuated between 3 and 10 per

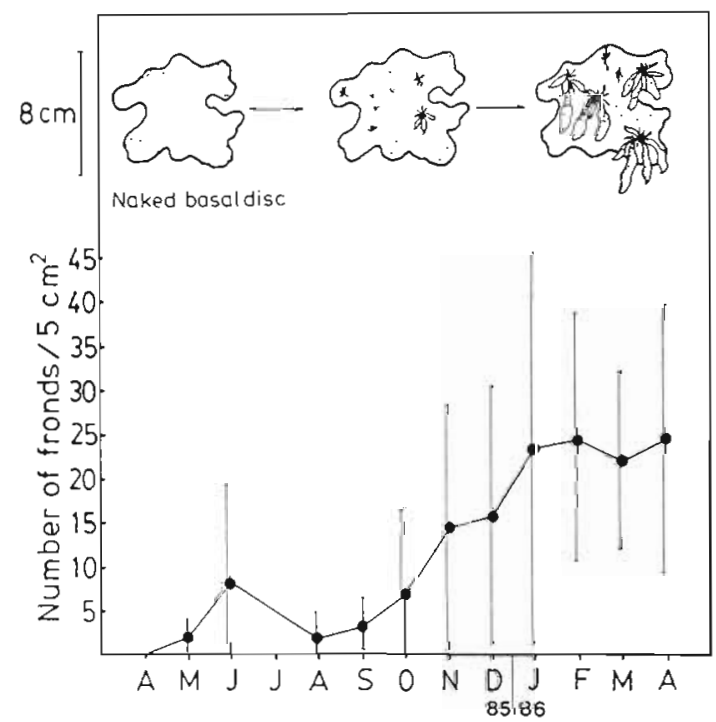

Fig. 3. Iridaea laminarioides. Monthly variation of number of fronds arising from crustose basal discs which were initially naked. Upper diagram illustrates the patchy frond formation throughout the time. Data are means \pm SD
$5 \mathrm{~cm}^{2}$. During summer and autumn, a strong increase was registered, with maximal values close to 25 fronds, after which the number of fronds remained stable.

\section{Effect of pruning}

Fig. 4 shows the results of pruning at stipe level and the total removal of fronds. During the first months, the regenerative activity of the basal disc was low, principally in the treatment pruning at stipe level. This low frond count seems to be caused by spatial interference by shoots of the stipe pruned, which continued during the course of the study. A low rate of frond production was also observed in the control plants, which during the first months maintained a stable number of fronds (between 20 and 28 fronds $5 \mathrm{~cm}^{-2}$ until early summer). New frond formation begins in the warmer months.

The plants submitted to total frond removal (pruned flat to the disc) exhibited a strong increase in the number of fronds between August and December, and reached a maximum value of 95 fronds. By the same means, controls considerably increased their frond formation rates, though much later. Anova confirms that seasons as well as treatments exert a significant effect upon frond production (Table 1).

Table 1. Summary of 2-way Anova for number of fronds between treatments and seasons. Mixed model Anova was used and data were analyzed as a randomized complete blocks design, where the months constitute a random effect. and treatments are fixed

\begin{tabular}{|lrrr|}
\hline Variation source & df & MS & \multicolumn{1}{c|}{$F$} \\
\hline Months & 9 & 1262.2 & $3.42^{\circ}$ \\
Treatments & 2 & 6036.1 & $16.38^{*}$ \\
Error & 18 & 368.3 & \\
Total & 29 & & \\
p $<0.05 ; \cdots p<0.01$ & & \\
\hline
\end{tabular}

Fig. 4. Iridaea laminarioides. Temporal changes in the number of fronds following 2 distinct pruning treatments. Data are means $\pm \mathrm{SD}$

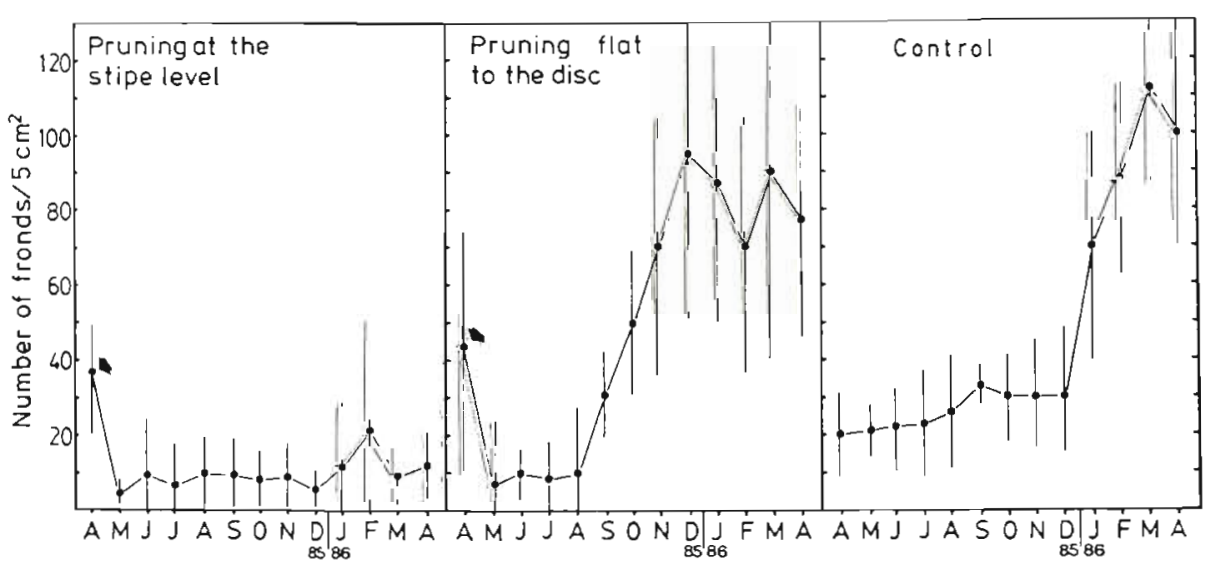


The response of Iridaea laminarioides to an intense regime of pruning is illustrated in Fig. 5. The seasonal pattern in frond formation observed in the treatment with only one pruning and in that with control plants is seen to be significantly altered by fortnightly harvests.

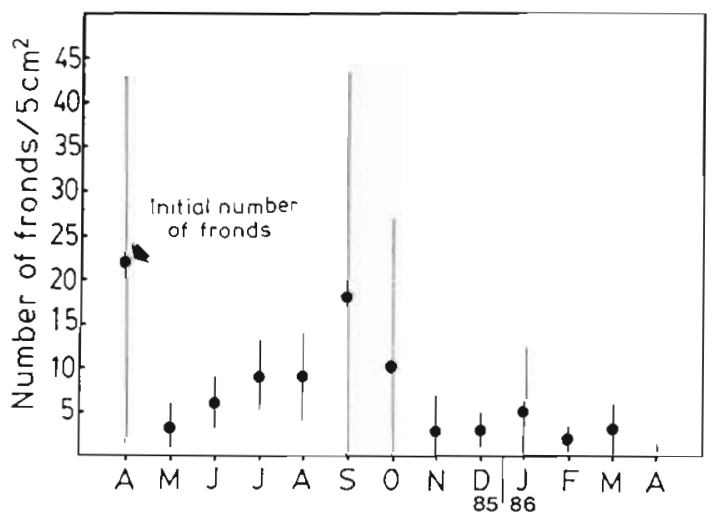

Fig. 5. Iridaea laminarioides. Temporal changes in the number of fronds following fortnightly pruning at the stipe level. Data are monthly averages $\pm S D$

Frond formation was stimulated by pruning during the first months, reaching a maximum in September (18 fronds $5 \mathrm{~cm}^{-2}$ ). However, in the next months, the regenerative capacity of the basal disc began to decrease, accompanied by the establishment of epiphytic algae Enteromorpha spp. and the bivalve Perumytilus purpuratus.

Under a seasonal pruning scheme (Fig. 6), Iridaea laminarioides did not respond with a clear seasonal

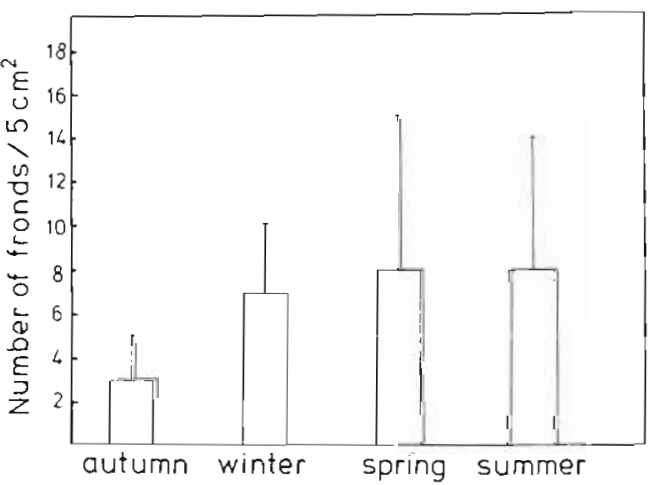

Fig. 6. Iridaed laminarioides. Seasonal response to pruning at the stipe level. Data are means $+\mathrm{SD}$ after $30 \mathrm{~d}$

component. During winter, spring and summer, frond formation did not vary significantly, reaching values of 7 to 8 fronds $5 \mathrm{~cm}^{-2}$ In autumn, the number of newly formed fronds after $30 \mathrm{~d}$ was reduced, but analysis of variance indicates no significant difference $(p>0.05)$.

\section{Population structure and frond growth rate}

During the course of the study Iridaed laminarioides fronds proved to be highly dynamic structures. The formation of fronds is a continuous process from the basal disc, allowing the presence of fronds in distinct development stages. The size distribution (Fig. 7) was determined principally by the loss of fronds longer than $12 \mathrm{~cm}$. During autumn and winter, classes of under $6 \mathrm{~cm}$ were strongly represented, constituting ca $80 \%$ of

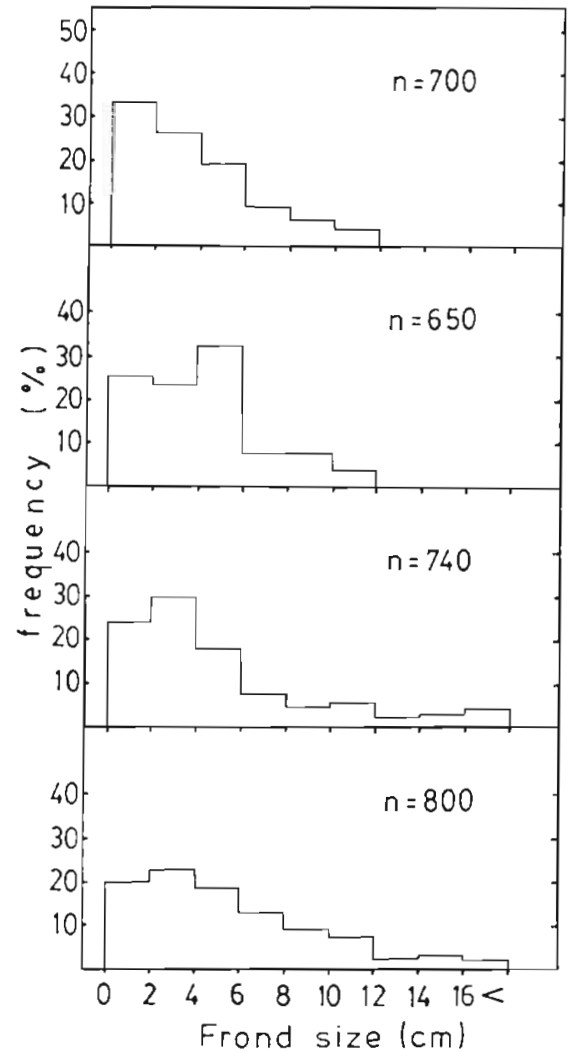

Fig. 7 Iridaea laminarioides. Seasonal variation in frond size structure

the total. Towards spring, stronger frond growth and reduced frond loss caused by physical stress permitted fronds of greater length to be found. Nevertheless, the population structure remained dominated by classes of less than $6 \mathrm{~cm}$. In summer, although frond formation from the basal disc was intense, an increase in the frequency of medium sized fronds was observed, which led to a greater homogeneity in the population structure.

Comparing frond growth rates in the experimental treatment and control plants (Fig 8), significant growth of plants submitted to the initial pruning was observed. Elimination of the canopy favoured growth from the basal disc, which was continuous throughout the year 


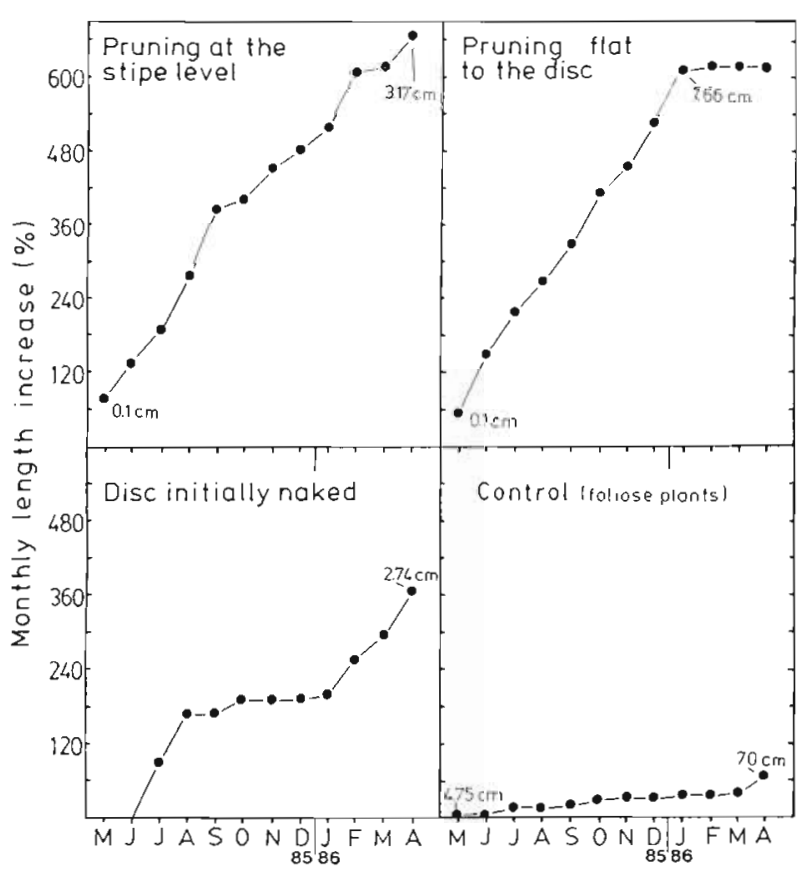

Fig. 8. Iridaea laminarioides. Frond growth rate for 2 pruning treatments and 2 controls (initially naked discs and frondose plants)

in the stipe level prunings. In the treatment with total removal of fronds (pruning flat to the disc), growth was accelerated during the first months, and later, when the fronds reached an average maximum size of $7.6 \mathrm{~cm}$, mortality began in the large fronds, thus stabilizing the average plant size. This situation was clearly observed in control, where the growth of the fronds was low, with a mean annual increment of only $60 \%$.

The growth of the fronds originating from the basal discs which were initially naked and unmanipulated continued a pattern of more moderate growth than the plants which were submitted to pruning. It was observed that the frond growth rate diminished in spring and summer and strongly increased in the autumn. Probably the fronds originating from basal disc without manipulation require a greater growth time in order to reach the size of the control.

\section{Frond regeneration in relation to isomorphic phase}

According to Westermeier et al. (1987a), in southern Chile, the isomorphic phases of Iridaea laminarioides are found in close to a 1:1 ratio. Taking into account that both tetrasporic and cystocarpic phases are submitted to the same harvesting pressure, it was possible to compare their responses to experimental prunings. It was observed that the 2 phases react in a similar way to

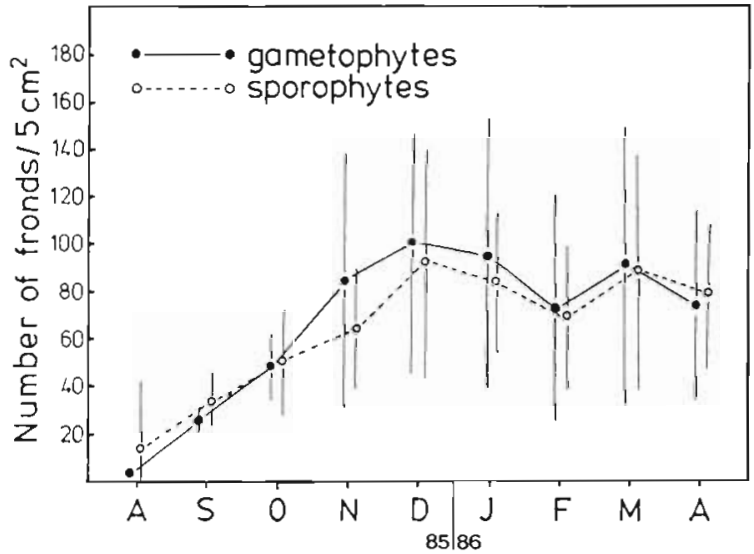

Fig. 9. Iridaea laminarioides. Comparative frond regrowth between gametophytic and tetrasporic plants. Data are means $\pm \mathrm{SD}$. One-way Anova indicates no significant differences $(\mathrm{p}>0.05)$

the removal of fronds (Fig. 9). During the first 5 mo the cystocarpic and tetrasporic phases exhibited a sustained increase in the number of fronds, stabilizing at values close to 100 fronds $5 \mathrm{~cm}^{-2}$. In seasonal pruning (Fig. 10), the cystocarpic plant had produced a greater number of tronds after $30 \mathrm{~d}$, but the differences were not statistically significant.

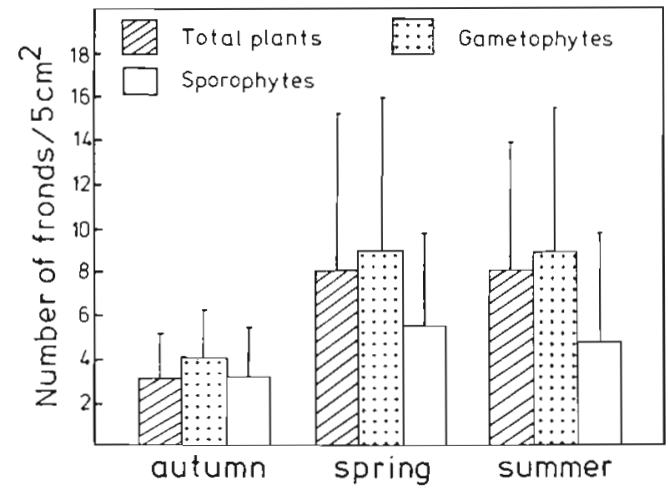

Fig. 10. Iridaea laminarioides. Response of isomorphic phases to seasonal pruning. Data are means + SD. One-way Anova indicates no significant differences $(p>0.05)$

The maturation of reproductive structures in both phases showed a clear seasonal pattern (Table 2). In general reproductive maturation occurred between January and March, when the plants had reached lengths greater than $14 \mathrm{~cm}$. Nevertheless, when pruning was performed much later (spring), the critical length of maturation of the fronds decreased, and it was possible to find reproductive fronds of less than $10 \mathrm{~cm}$ in length. 
Table 2. Iridaea laminarioides. Changes in reproductive capacity following seasonal pruning. Data refer to the first reproductive frond that appeared after pruning

\begin{tabular}{|lccc|}
\hline Pruning date & $\begin{array}{c}\text { Date of } \\
\text { appearance }\end{array}$ & $\begin{array}{c}\text { Size } \\
(\mathrm{cm})\end{array}$ & Phase \\
\hline Apr 1985 (autumn) & Feb 1986 & 14.0 & Cystocarpic \\
Jul 1985 (winter) & Jan 1986 & 15.0 & Tetrasporic \\
& Mar 1986 & 14.0 & Cystocarpic \\
Oct 1985 (spring) & Mar 1986 & 9.0 & Tetrasporic \\
Jan 1986 (summer) & No reproductive fronds were found \\
\hline
\end{tabular}

\section{DISCUSSION}

Our results indicate that frond regrowth from basal disc in Iridaea laminarioides is regulated by seasonal changes, reinforcing previous observations on biomass carried out at Mehuín by Westermeier et al. (1987a). We found that complete removal of the fronds stimulates the formation of new fronds from the basal disc. This marked increase in the activity of basal discs that are deprived of their fronds is not surprising. Studies on Chondrus crispus demonstrated that selective removal of fronds induced the maintenance of a high productivity (Bhattacharya 1985, McLachlan et al. 1988, 1989, Lazo et al. 1989). These authors suggested that the morphology of C. crispus has evolved in such a way that frond formation permits ecological success and, moreover, sustained commercial exploitation. In the present study, plants submitted to fortnightly removal of fronds showed a strong frond regrowth during the first $5 \mathrm{mo}$, but later a reduction in the ability of the basal disc to produce fronds became evident. It seems to be that an intensive regime of pruning suppresses the productivity of $I$. laminarioides, depleting their energetic reserves as suggested by Poblete \& Lafón (1987). Moreover, analysis of $I$. laminarioides has revealed seasonal variations in proteins, lipids and carbohydrates (Westermeier et al. 1987b), which may be used to explain physiological mechanisms in the frond formation from the basal disc, or as a basis for delineating a commercial harvesting program.

In Iridaea laminarioides, after the initial size of the plant is regained, further vegetative regrowth declines. It may be that frond formation is related primarily to light competition and subject to interference between the fronds. It is interesting that, following seasonal pruning, no considerable differences in the regenerative responses were found. Even during low light conditions, the pruned plants exhibited high production and growth of fronds. This pattern appears to be consistent with the idea proposed by Hellebust (1970), that young or small fronds require lower irradiance levels for their development.

McLachlan et al. (1988, 1989), in studies on Chondrus crispus, showed that demographic components related to frond density cause differential growth rates among the fronds, suggesting that the frond size was probably not correlated with frond age. Our results indicate that the size structure of Iridaea laminarioides is determined by losses of larger fronds, especially during autumn and winter, i.e. is regulated by seasonal factors. Likewise, a clear relationship between the density of fronds and frond size was found (Table 3).

Table 3. Iridaea laminarioides. Relationship between frond size $(y)$ and density $(x)$. Data were taken during 2 development stages of the plants: during high frond formation allowing pruning, and stabilized phase. $\mathrm{n}=20$ plants

\begin{tabular}{|lll|}
\hline & Equation & $\begin{array}{c}\text { Correlation } \\
\text { coefficient }(r)\end{array}$ \\
\hline High proliferation phase & $y=2.20+0.001 x$ & $0.86^{\cdots}$ \\
Stabilized phase & $y=4.92+0.01 x$ & $0.45^{\circ}$ \\
$p<0.05 ; \cdots p<0.01$ & & \\
\hline
\end{tabular}

The correlation indices suggest a greater relationship between the 2 parameters $(r=0.86, p<0.01$ ) during the stage of high proliferation and growth of fronds, but, when the plant regained its initial shape (before pruning), the relationship between density and size declined $(\mathrm{r}=0.42, \mathrm{p}<0.01)$. These results suggest that in I. laminarioides, like C. crispus, the interactions between fronds of individual plants are of primary importance.

It has been indicated that the structure of individual plants is directly related to the reproductive capacity (Silvertown 1982). This is significant in Iridaea laminarioides as the size structure is determined by seasonality. Most of the reproductive fronds occurred between spring and early autumn, and it was noted that the mature fronds generally exceeded $12 \mathrm{~cm}$. Thus, reproduction appears to be regulated by frond growth rate. A similar reproductive pattern has been reported for Chondrus crispus (McLachlan et al. 1988, 1989, Lazo et al. 1989). In pruning treatments performed in April 1985 (autumn), reproductive fronds were found after $9 \mathrm{mo}$, while plants pruned towards winter and spring were shown reproductive after 6 and 5 mo respectively. According to Mathieson \& Burns (1975), stands of C. crispus submitted to pruning require between 4 mo and $3 \mathrm{yr}$, depending on the degree of harvesting, to recover their reproductive capacity. Although I. laminarioides has reproductive fronds throughout the year (Westermeier et al. 1987a), 
the turnover rate of fronds suggests that reproduction from spores probably constitutes a secondary mechanism in the population maintenance. Larger fronds, which were commonly found mature, are removed more easily from the basal disc by physical forces. Similarly, a strong inverse relationship between the size of the reproductive fronds and their life expectancy has been observed for C. crispus (Bhattacharya 1985), emphasizing the apparent unimportance of reproduction through spores in these heterotrichous species. However, McLachlan et al. (1988) postulate that the losses of mature fronds can result in a wider dispersal of spores than if the fronds remain attached. Although this strategy can be active in populations of $I$. laminarioides, there is evidence to support the idea that the disc is the principal mechanism for securing space and maintaining ecological dominance (Jara \& Moreno 1983, Gómez 1987, Westermeier et al. 1987a), while reproduction from spores represents an alternative way when the basal disc is damaged or removed, or during massive colonization of new primary space. Thus, when the substratum is not limiting, propagules of both gametophytic and sporophytic generations have comparable chances of becoming established (May 1986, Lazo et al. 1989, Luxoro \& Santelices 1989). Such a situation may explain the characteristic $1: 1$ gametophytic-sporophytic ratio in the population of $I$. laminarioides observed in the present study and previously reported by Westermeier et al. (1987a).

Literature on the ecological differsuces between the isomorphic phases in the Gigartinaceae is confused and does not present a uniform pattern. Species such as Iridaea flaccida, Gigartina corymbifera and Rhodoglossum affine from California (Abbott 1980), and Chondrus crispus in the North Atlantic (Mathieson \& Burns 1975. MacLachlan et al. 1988, 1989, Lazo et al. 1989), show a higher proportion of gametophytes, whereas $I$. cordata in Central California was reported as consisting predominantly of the sporophytic phase (Hansen \& Doyle 1976). Populations of $I$. laminarioides from Mehuín exhibit a similar frequency of gametophytic and sporophytic phases (Westermeier et al. 1987a) and in our study no significant differences in pruning response were detected. We thus speculate that no demographic or physiological differences exist between gametophytes and tetrasporophytes of $I$. laminarioides, because their occurrence appears to be similar. More detailed analysis of the isomorphic reproductive phases had been described by Hannach \& Santelices (1985), Lazo et al. (1989) and Luxoro \& Santelices (1989).

The presence of a perennial basal disc in many algae has been considered as a strategy for survival in environments submitted to strong perturbation or where space is a limiting resource (Dixon 1973, Daly \&
Mathieson 1977, Hansen 1977, Littler \& Littler 1980 , Littler \& Kauker 1984, D'Antonio 1986). This is significant when the species considered, such as Iridaea laminarioides, has an isomorphic life-history. At present, hypotheses on the origin of the alternating morphofunctional phases suggest a disruptive selection mechanism operating on the morphology (Istock 1967, Lubchenco \& Cubit 1980, Hannach \& Santelices 1985), but it is questionable whether there is a close evolutionary relationship between heteromorphic and isomorphic life-history (Stebbing \& Hill 1980, Clayton 1988, Maggs 1988).

In southern Chile, the population dynamics of Iridaea laminarioides, or at least its maintenance, undoubtedly depends on the presence of a perennial basal disc; however, much of its physiology is unknown. Abiotic factors related to environmental changes (Westermeier \& Rivera 1986, Gómez 1987, Westermeier et al. 1987a) and sand level variation (Pino 1982, Gómez 1987) interact with biological regulators such as herbivory and competition (Jara \& Moreno 1983, Moreno \& Jaramillo 1983). Perhaps other endogenous factors are also involved, compensating for the environmental effect. In this respect, Perrone \& Felicini (1988) suggested that an endogenous hormonal mechanism (switched by environmental factors) acts on the morphological alternation in Scottera nicaeensis, producing a viable perennial thallus which operates as storage organ and is resistant to grazing and other perturbating agents. This may explain the presence of 2 different alternating vegetative forms in species that do not have a heteromorphic life-history. Thus, the efficient vegetative maintenance occurring in $I$. laminarioides would involve a morphogenetic change as suggested by Per-
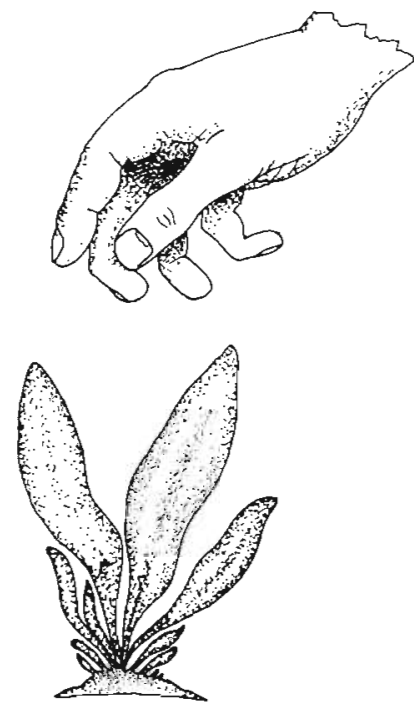

Fig. 11. Schematic drawing showing the proposed harvesting method, which only removes large fronds 
rone \& Felicini (1988). More detailed ecophysiological studies will be required in order to interpret correctly the biology of this important species.

Finally, it must remembered that, while Iridaea laminarioides is an ecologically successful species, much of its dominance is related to the regenerative capacity of the basal disc. Thus for management purposes, a rational harvest technique must be developed in order to maintain a high level of productivity. We believe that large fronds could be removed as shown in Fig. 11, allowing continuous frond regrowth. Additionally, and taking into account the temporal variation of chemical contents reported by Westermeier et al. (1987b), the harvesting period should be concentrated between spring and autumn, when fronds exhibit a greater growth rate.

Acknowledgements. This study was made possible by financial support to the co-author by the Organisation of American States (Grant CHI-01-84-84 of PRDCYT), the Direccion de Investigación y Desarrollo de la Universidad Austral de Chile (Grant RS-82-37), and by the Volkswagen Fund of Germany. We thank D. G. Müller, M. Dethier, G. T Boalch and 3 anonymous reviewers for valuable suggestions and comments improving the manuscript. In addition we acknowledge $J$. Ablard for help in the English presentation.

\section{LITERATURE CITED}

Abbott, I. A. (1980). Seasonal population biology of some carrageenophytes and agarophytes. In: Abbott, I. A., Foster, M., Eklund, L. F. (eds.) Pacific seaweed aquaculture. California Sea Grant College Program, La Jolla, p. 45-53

Bhattacharya, D. (1985). The demography of fronds of Chondrus crispus (Stackhouse). J. exp. mar. Biol. Ecol. 91: $217-231$

Clayton, M. (1988). Evolution and life histories of brown algae. Botanica mar. 31: 379-387

Daly, M. A., Mathieson, A. C. (1977). The effects of sand movement on intertidal seaweeds and selected invertebrates at Bound Rock, New Hampshire, USA. Mar Biol. 43: $45-56$

D'Antonio, C. M. (1986). Role of sand in the domination of hard substrata by the intertidal alga Rhodomela larix. Mar. Ecol. Prog. Ser 27: 263-275

Dixon, P. S. (1973), Biology of the Rhodophyta. Hafner. New York

Gómez, I. (1987). Producción de frondas a partir del disco basal de Iridaea laminarioides Bory en Mehuín, Valdivia Tesis de Grado. Licenciatura en Ciencias, Universidad Austral de Chile

Guiller, E. R. (1959). The intertidal ecology of the Montemar area, Chile. Pap. Proc. R. Soc. Tasm. 93: 164-183

Hannach, G., Santelices, B. (1985). Ecological differences between the isomorphic reproductive phases of two species of Iridaea (Rhodophyta, Gigartinales). Mar Ecol. Prog. Ser 22: 291-303

Hansen, J. E. (1977). Ecology and natural history of Iridaea cordata (Rhodophyta, Gigartinales): growth. J. Phycol. 13 $395-402$

Hansen, J. E., Doyle, W T (1976). Ecology and natural history of Iridaea cordata (Rhodophyta, Gigartinaceae): population structure. J. Phycol. 12: 273-278

Hellebust, J. (1970). Light: Plants. In: Kinne, O (ed.) Marine ecology, Vol. 1. Environmental factors, Part 1. Wiley, London, p. $125-158$

Istock, C. A. (1967). The evolution of complex life cycle phenomena: an ecological perspective. Evolution 21: $592-605$

Jara, H. F., Moreno, C. A. (1983). Herbivory and structure in a midlittoral rocky community: a case in Southern Chile. Ecology 65: 28-38

Lazo, M. L., Greenwell, M., McLachlan, J. (1989), Population structure of Chondrus crispus Stackhouse (Gigartinaceae, Rhodophyta) along the coast of Prince Edward Island, Canada: distribution of gametophytic and sporophytic fronds. J. exp. mar. Biol. Ecol. 126: 45-58

Littler, M. N., Littler, D. S. (1980). The evolution of thallus form and survival strategies in benthic marine macroalgae: field and laboratory test of a functional form model. Am. Nat. 116: $25-44$

Littler, M. M., Kauker, B. J. (1984). Heterotrichy and survival strategies in the red alga Corallina officinalis. Botanica mar. 27: $37-44$

Lubchenco, J., Cubit, J. (1980). Heteromorphic life histories of certain marine algae as adaptations to variations in herbivory. Ecology 61: 676-687

Luxoro, C., Santelices, B. (1989). Additional evidence for ecological differences among isomorphic reproductive phases of Iridaea laminarioides (Rhodophyta: Gigartinales). J. Phycol. 25: 206-212

Maggs, C. A. (1988). Intraspecific life history variability in the Florideophycidae (Rhodophyta). Botanica mar. 31 $465-490$

Mathieson, A. C., Burns, R. L. (1975). Ecological studies of economic red algae. 5. Growth and reproduction of natural and harvested population of Chondrus crispus Stackhouse in New Hampshire. J. exp. mar. Biol. Ecol. 17: 137-156

May, G. (1986). Life history variations in a predominantly gamethophytic population of Iridaea cordata (Gigartinaceae, Rhodophyta). J. Phycol. 22: 448-455

McLachlan, J., Lewis, N., Lazo, M. (1988). Biological considerations of Chondrus crispus Stackhouse (Rhodophyta, Gigartinaceae) in the Southern Gulf of St. Lawrence, Canada. Gayana Bot. 45: 29-54

McLachlan, J., Quinn, J., McDougall, C. (1989). The structure of the plant of Chondrus crispus Stackhouse (Irish moss). J. appl. Phycol. 1: 311-317

McLean, J. H. (1978). Systematics of Fissurella (Gastropoda: Prosobranchia) in the Peruvian and Magellanic faunal provinces. Contr. Sci. 354: 1-126

Moreno, C. A., Jaramillo, E. (1983). The role of grazers in the zonation of intertidal macroalgae of the Chile coast near Valdivia. Oikos $41 \quad 73-76$

Oliva, M. A. (1967). Contribución al estudio de la flora algológica de Mehuín, Valdivia. Tesis, Escuela de Biología y Química, Universidad Austral de Chile, Valdivia

Perrone, C., Felicini, G. P. (1988). Physiological ecology of Schottera nicaeensis (Phyllophoraceae, Rhodophyta) : functional significance of heterotrichy. Phycologia 27: 347-354

Pino, M. (1982). Interpretacion granulométrica a través de componentes principales de la dinánica anual de acreción - erosión en Playa Pichicullín, Mehuín, Provincia de Valdivia. Actas III Congreso Geológico Chileno, Universidad de Concepción, p. 36-68

Poblete, A., Lafón, A. (1987). Nota sobre el comportamiento de los discos basales de Iridaea ciliata Kutzing. Medio ambiente 8: 90-94 
Ponce, F. (1987). Antecedentes sobre la explotación del recurso Iridaea en Chile. Medio ambiente 8: 67-73

Santelices, B. (1981). Perspectivas de investigación en estructura y dinámica de comunidades intermareales rocosas de Chile Central. I. Cinturones de macroalgas. Medio ambiente 5: 175-189

Searles, R. (1980). The strategy of the red algal life history. Am. Nat. 115: 113-120

Silvertown, J. W. (1982). Introduction to plant population ecology. Longman, Essex

Sokal, R. R., Rohlf, F. J. (1969). Biometry. W H. Freeman and Co., San Francisco

Stebbins, G. L., Hill, G. J. (1980). Did multicellular plants invade land? Am. Nat. 115: 342-353

Westermeier, R. (1982). Zonierung, Biomasse, Energiegehalt und Schwermetallakumulation mariner Algen aus Chile,

This article was presented by J. E. Winter, Valdivia, Chile
Helgoland und Spanien. Inaugural Dissertation, JustusLiebig-Universität, Giessen

Westermeier, R., Rivera, P. J. (1986). Caracterización ficológica del intermareal rocoso de la $X$ región (Valdivia, Osorno, Llanquihue y Chiloé) y de la XIl región (I. Diego Ramirez), Chile. In: Westermeier, R. (ed.) Actas Il Congr. Algas Mar. Chilenas, Universidad Austral de Chile, p. 125-144

Westermeier, R., Rivera, P. J., Chacana, M., Gómez, I. (1987a). Biological bases for the management of Iridaea laminarioides Bory in Southern Chile. Hydrobiology 151/ 152: 313-328

Westermeier, R, Guaiquil, V H., Wenzel, H., Peruzzo, G. Kohler, N. (1987b). Variación de valores calóricos, cenizas, hidratos de carbono, lípidos y proteínas en frondas cistocárpicas y tetraspóricas de I. laminarioides Bory en el sur de Chile. Medio ambiente 8: 85-89

Manuscript first received: May 2, 1988

Revised version accepted: March 27, 1991 